\title{
INFLUENCE OF FOREST COVERAGE IN THE SURFACE ALBEDO
}

\author{
Elisiane Alba ${ }^{1 *}$, Juliana Marchesan², Mateus Schuh², José Augusto Spiazzi Favarin³ ${ }^{3}$ Emanuel Araújo \\ Silva ${ }^{4}$, Rudiney Soares Pereira ${ }^{5}$ \\ 1* Federal University of Santa Maria, Postgraduate Program in Forest Engineering, Santa Maria, Rio Grande do Sul, Brazil - \\ elisianealba@gmail.com \\ ${ }^{2}$ Federal University of Santa Maria, Postgraduate Program in Forest Engineering, Santa Maria, Rio Grande do Sul, Brazil - \\ marchesan.ju@gmail.com, mateuschuh@gmail.com \\ ${ }^{3}$ Federal University of Paraná, Postgraduate Program in Forest Engineering, Curitiba, Paraná, Brazil - jasflorestal@yahoo.com.br \\ ${ }^{4}$ Federal Rural University of Pernambuco, Forest Science Department, Recife, Pernambuco, Brazil - emanuel.ufrpe@gmail.com \\ ${ }^{5}$ Federal University of Santa Maria, Rural Engineering Department, Santa Maria, Rio Grande do Sul, Brazil - \\ rudiney.s.pereira@gmail.com
}

Recebido para publicação: 19/07/2018 - Aceito para publicação: 11/04/2019

\begin{abstract}
Resumo
Influência da cobertura florestal no albedo de superfície. O albedo de superfície controla o balanço de energia entre a superfície e a atmosfera, sendo uma variável primordial para identificar variações climáticas. O objetivo deste estudo foi avaliar as mudanças no albedo de superfície em diferentes usos e cobertura da terra presentes no bioma Mata Atlântica a partir de imagens TM/Landsat 5 e OLI/Landsat 8, verificando a sua variação no período de 30 anos. As imagens utilizadas foram da órbita-ponto 221-080, as quais recobriram a Floresta Nacional de São Francisco de Paula nas datas de 1987 e 2017. O albedo foi obtido por meio do método de Surface Energy Balance Algorithm for Land, enquanto o mapeamento do uso e cobertura da terra foi realizado pelo algoritmo Bhattacharyya, identificando quatro classes temáticas. Por fim, realizou-se o cruzamento do albedo com as classes temáticas evidenciando a sua variação em função das mudanças na cobertura da terra. $\mathrm{O}$ albedo de superfície variou de 6 a 22\%, porém o ano de 1987 concentrou valores de albedo superiores à 2017. A Floresta nativa apresentou albedo superior aos Plantios florestais em ambas as datas, decorrente da estrutura do dossel desta classe. A análise espacial do albedo expôs a relação dessa variável climática com a cobertura da superfície terrestre. Desse modo, mudanças na cobertura vegetal ocasionam alterações no albedo, influenciando em mudanças na radiação e fluxos da atmosfera.
\end{abstract}

Palavras-chave: Floresta nativa; Imagens Landsat; Mudanças climáticas.

\begin{abstract}
The surface albedo controls the energy balance between the surface and the atmosphere, being a primordial variable to identify climatic variations. The objective of this study was to evaluate the changes of the surface albedo in different Land Use and Land Cover in the Atlantic Forest biome from images TM/Landsat 5 and OLI/Landsat 8, verifying its variation in 30 years. The images used were path-row 221-080, which covered the Floresta Nacional de São Francisco de Paula on the dates of 1987 and 2017. The albedo was obtained by the method of the Surface Energy Balance Algorithm for Land, while the mapping of Land Use and Land Cover was performed by the Bhattacharyya algorithm, identifying four thematic classes. Finally, the albedo was crossed with the thematic classes, evidencing their variation in function of the changes in the land cover. The surface albedo ranged from 6 to $22 \%$, but the year 1987 concentrated albedo values higher than in 2017. The native forest presented superior albedo to the Forest Plantations in both dates due to the structure of the canopy of this class. The spatial analysis of the albedo exposes the relation of this climatic variable to the cover of the terrestrial surface. Thus changes in the vegetation cover cause alterations in the albedo, influencing changes in the radiation and atmospheric fluxes.
\end{abstract}

Keywords: Native forest; Landsat images; Climate changes.

\section{INTRODUCTION}

The replacement of native forest cover in alternative land uses led to a growing interest in the climate effects resulting from this conversion. This process has led to the development of studies that more accurately describe the interaction mechanisms of vegetation with the atmosphere fluxes. Thus, the albedo is an important parameter to evaluate the relation of forests to the balance of atmospheric energy.

FLORESTA, Curitiba, PR, v. 50, n. 1, p. $1011-1020$, jan/mar 2020.

Alba, E. et.al.

ISSN eletrônico 1982-4688

DOI: $10.5380 /$ rf.v50 i1.60595 
Listed by the Global Climate Observation System (Global Climate Observation System - GCOS), albedo is one of the key climate variables, considered the key that controls the planetary radiative energy balance and the energy portion between the atmosphere and the Earth's surface (LUKES et al. 2014), represented as the integration of reflectance along the solar radiation spectrum. The changes in albedo modify the radiation and energy balance of the surface, which can be detected with its monitoring (SILVA et al., 2016).

Hahmann and Dickinson (1997), when developing modeling of climate, they have identified that changes in surface albedo and vegetation roughness correspond to the two most important biophysical properties influencing the local climate. When assessing this climate variable with the use of Earth coverage, Davin and Noblet-Ducoudré (2010) detected that the loss of forest cover generates an increase of the surface albedo, reducing evapotranspiration and surface roughness, which leads to heating of local climate (LI et al., 2008).

The relationship between the forest surface and its albedo is complex, and for Lukes et al. (2013) this variable is little studied, especially concerning the influence of natural disturbances and human activities (forest management) on albedo variation. The incidence of this variable is still unknown when it comes to tropical forests, such as the Atlantic Forest.

Satellite observation corresponds to the only viable means of monitoring the albedo over time and space (KUUSINEN et al., 2013). Remote sensing allows the integration of information and processes related to the exchange of carbon, gases, water, and energy between biosphere and atmosphere (LIBERATO, 2011).

The use of orbital images presents as a tool to be exploited due to its spectral characteristic, which allows a deepening of agrometeorological components such as albedo, vegetation indices, surface temperature, among others (JENSEN, 2009). The data from remote sensing allow the knowledge of the forest cover reflectance, making it possible to link quantitative changes in the vegetation structure to the albedo for regions of interest (LUKES et al., 2013).

The estimation of large-scale surface albedo is often performed from low and medium spatial resolution reflectance data (LUKES et al., 2014). In this perspective, the data of the Moderate-Resolution Imaging Spectroradiometer (MODIS) sensor are used to estimate the albedo of large regions (PLANQUE et al., 2017; LUKES et al., 2016; LUKES et al., 2014) while Landsat images are intended for smaller scales (KUUSINEN et al., 2016; GIONGO; VETTORAZZI, 2014; LIBERATO, 2011).

Data from the Land Remote Sensing Satellite (Landsat) satellite have the potential for use in surface albedo estimates in applications that require data with finer spatial resolution such as monitoring fragmented areas (HE et al., 2018). In this sense, the Atlantic Forest biome is highly fragmented, and the uniform areas are usually a few hectares. In this perspective, the albedo products based on MODIS sensor data present a spatial resolution of approximately 25 ha, not including the particularities of these fragments, which can be better represented when using Landsat images.

The objective of this study was to evaluate the occurrence of surface albedo in different uses and land cover in the Atlantic Forest biome from TM/Landsat 5 and OLI/Landsat 8 images over 30 years.

\section{MATERIALS AND METHODS}

\section{Characterization of the study area}

The National Forest (FLONA) of São Francisco de Paula is located in São Francisco de Paula, in the northeast of the state of Rio Grande do Sul, Brazil (Figure 1). FLONA is located between 29 27'29.91 "at

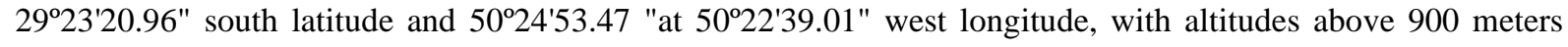
(ICMBIO, 2017).

The FLONA of São Francisco de Paula is characterized by the Climate Fields of the Mountain (Steppe) and by the forests with Araucaria, the Mixed Ombrophilous Forest, whose phytophysiognomies belong to the Atlantic Forest biome. The region has an annual rainfall of over 2,000 mm, associated with an annual average temperature of approximately $14.5^{\circ} \mathrm{C}$ (KANIESKI et al., 2017). Negative temperatures can occur from April to November, when frosts are frequent, counting even on the formation of snow in the most rigorous winters (SONEGO et al., 2007). 


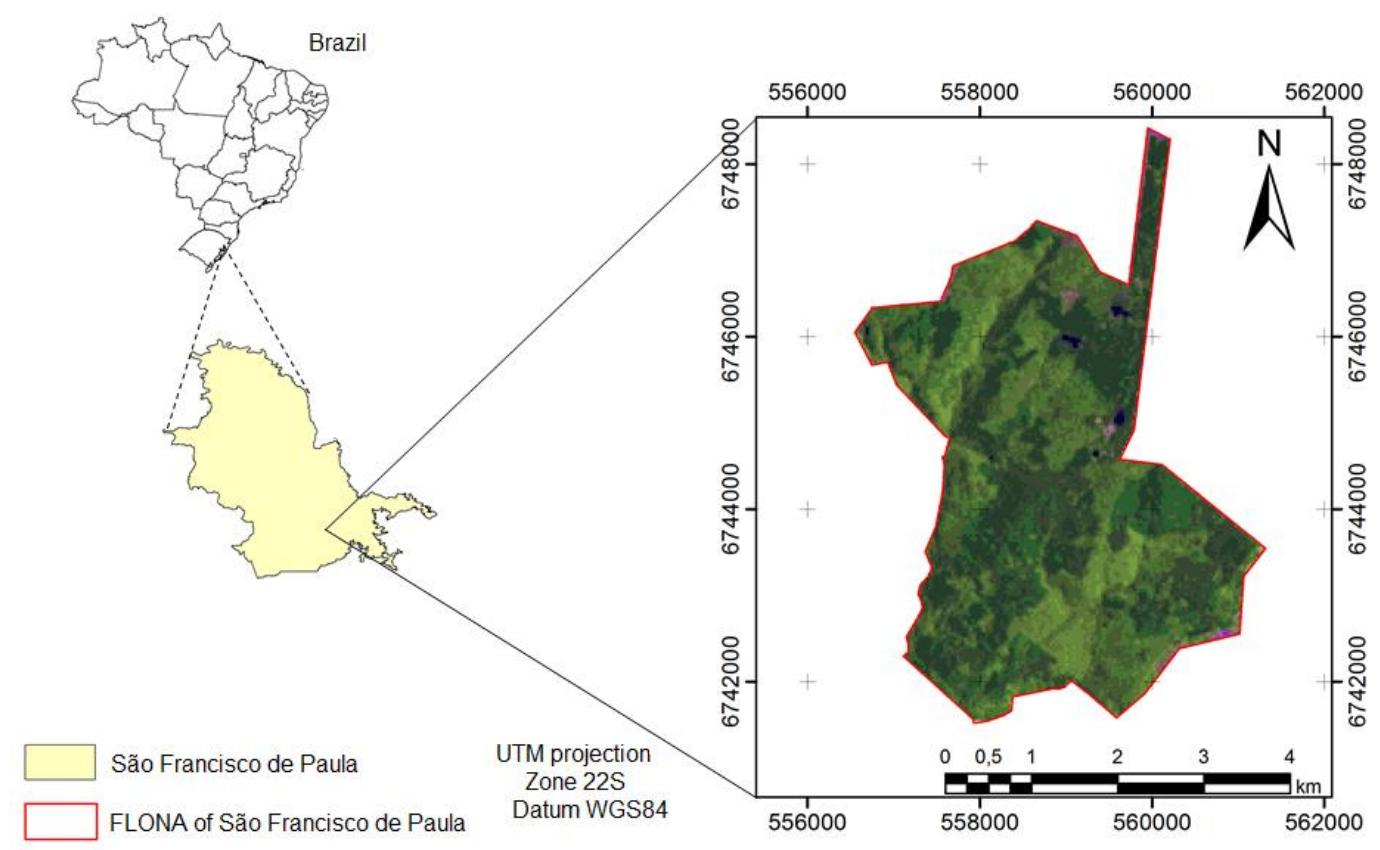

Figure 1. Location of the area of study.

Figura 1. Localização da área de estudo.

The area is composed of reforestation of Araucaria angustifolia (Bertol.) Kuntze, Pinus taeda L., Pinus elliottii Engelm. and Eucalyptus spp. L'Hér. FLONA has other species, with less representativeness for commercial purposes, totaling a coverage by the forest plantations of approximately 600 ha. However, most of the FLONA is occupied by the native forest, being approximately 900 ha (KANIESKI et al., 2017).

\section{Spectral data}

The albedo of vegetated surfaces is controlled by climatic variation, especially in environments that have a marked seasonality, since abiotic climate factors influence the physiological properties of the vegetation. Thus, the study used images in the orbit-dot 221-080 of the Landsat 5 satellites, the TM sensor (Thematic Mapper) dated 02/28/1987, and Landsat 8, OLI (Operational Land Imager) sensor on 01/13/2017, both in the summer period.

The estimation of the albedo involves values of reflectance of the earth surface. Thus, the data were subjected to the conversion of the digital numbers into reflectance at the top of the atmosphere. The spectral radiance of each band $\left(\mathrm{L}_{\lambda}\right)$ of the TM/Landsat 5 sensor was calculated by equations 1 and 2 , which corresponds to the output radiation of the band observed at the top of the atmosphere. From the spectral radiance, the planetary reflectance (from the $\rho_{\lambda}$ ) spectral bands of the TM sensor was obtained, as described by the United States Geological Survey (USGS, 2017).

In which:

$$
\begin{aligned}
& \mathrm{L}_{\lambda}=\frac{\mathrm{L}_{\text {Máx }}-\mathrm{L}_{\mathrm{Min}}}{255} * \mathrm{ND}+\mathrm{L}_{\mathrm{Min}} \\
& \rho_{\lambda}=\frac{\pi^{*} \mathrm{~L}_{\lambda} * \mathrm{~d}_{\mathrm{r}}{ }^{2}}{\operatorname{ESUN}_{\lambda}{ }^{*} \cos \theta}
\end{aligned}
$$

$\mathrm{L}_{\lambda}=$ spectral radiance of each band, expressed in unit $\mathrm{m}^{-2} / \mathrm{sr} / \mu \mathrm{m}$;

$\mathrm{L}_{\mathrm{Max}}$ and $\mathrm{L}_{\mathrm{Min}}=$ sensor calibration constants;

$\mathrm{ND}=$ digital number of each pixel;

$\rho_{\lambda}=$ reflectance at the top of the atmosphere;

$\mathrm{dr}=$ relative distance between Earth and Sun, available in the metadata.

$\operatorname{ESUN}_{\lambda}=$ corresponds to solar eixo-atmospheric irradiance for each band $\left(\mathrm{W} / \mathrm{m}^{2} / \mu \mathrm{m}\right)$;

$\cos \theta=\operatorname{cosine}$ of the angle of the zenith angle; 
The conversion of the digital numbers into reflectance for OLI/Landsat 8 images presents modifications in relation to the other satellites of the Landsat series. Thus, obtaining planetary reflectance values is done through parameters available in the metadata of the images, according to Equation 3 (USGS, 2017).

$$
\rho=\frac{M_{\rho} * Q_{c a l}+A_{\rho}}{\operatorname{Sin}\left(\Theta_{S E}\right)}
$$

In which:

$\rho=$ planetary reflectance at the top of the atmospheric;

$\mathrm{M} \rho=$ multiplicative scaling factor of the specific band;

Qcal = quantized value calibrated by the pixel in ND;

A $\rho=$ additive scaling factor specific to the band from the metadata;

$\Theta_{\mathrm{SE}}=$ solar elevation angle.

\section{Surface Albedo}

To estimate albedo $(\alpha)$, the Surface Energy Balance Algorithm for Land (SEBAL) model proposed by Bastiaanssen (1995) was used, as shown in Equation 4. The atmospheric albedo $\left(\alpha_{\text {atm }}\right)$ was obtained with the radiative transfer model, where the value of this variable recommended for the SEBAL model is 0.03 (LIBERATO, 2011; SILVA et al., 2016). Transmissivity $\left(\tau_{\mathrm{oc}}\right)$ for clear sky conditions was described by Allen et al. (2007) (Equation 5).

In which:

$$
\alpha=\frac{\alpha_{\text {toa- }} \alpha_{\text {atm }}}{\tau_{\mathrm{oc}}^{2}}
$$

$\alpha=$ surface albedo;

$\alpha_{\text {toa }}=$ albedo at the top of the atmosphere (planetary);

$\alpha_{\mathrm{atm}}=$ atmospheric albedo;

$\tau_{\mathrm{oc}}^{2}=$ atmospheric transmissivity.

$$
\tau_{\mathrm{oc}}=0.35+0.627 \exp \left[-\frac{0.00146 \mathrm{P}_{\mathrm{o}}}{\mathrm{K}_{\mathrm{t}} \cos \mathrm{Z}}-0.075\left(\frac{\mathrm{W}}{\cos \mathrm{Z}}\right)^{0.4}\right]
$$

Po $=$ local atmospheric pressure $(\mathrm{kPa})$;

$\mathrm{Kt}=$ air turbidity coefficient (1.0 is for clean air and 0.5 is for extremely cloudy or polluted air);

$\mathrm{Z}=$ zenith angle;

$\mathrm{W}=$ rainfall $(\mathrm{mm}): \mathrm{W}=0,14 \mathrm{e}_{\mathrm{a}} \mathrm{P}_{\mathrm{o}}+2,1$ and $\mathrm{e}_{\mathrm{a}}$ corresponds to the atmospheric water vapor partial pressure $(\mathrm{kPa})$.

The albedo at the top of the atmosphere $\left(\alpha_{\text {toa }}\right)$ is obtained through the linear combination of the reflectance of each band with their respective weights. Thus, for TM/Landsat 5 sensor images, weights were used as described in Equation 6. Bands 1, 2, 3, 4, 5, and 7 are the TM/Landsat sensor bands.

$$
0.293 \rho_{1}+0.274 \rho_{2}+0.233 \rho_{3}+0.157 \rho_{4}+0.033 \rho_{5}+0.011 \rho_{7}
$$

However, for OLI/Landsat 8 images, the weights used are shown in Equation 7. The spectral bands encompassed for this sensor are bands 2, 3, 4, 5, 6 and 7, respectively. The conversion of digital numbers into reflectance, as well as the albedo estimates, were performed in $\mathrm{R}$ programming language, version 3.4.3 ( $\mathrm{R}$ DEVELOPMENT CORE TEAM, 2017). Functions were developed for these procedures.

$$
0.300 \rho_{2}+0.276 \rho_{3}+0.233 \rho_{4}+0.143 \rho_{5}+0.035 \rho_{6}+0.0119 \rho_{7}
$$

\section{Relationship of albedo with land use and cover}

For the mapping of the thematic classes present in the FLONA of São Francisco de Paula, the segmentation of the images was performed using the regions growth method. In this process, the division of the image into homogeneous regions is related to the parameters of similarity and area. After several tests on these parameters, for the TM/Landsat 5 sensor, parameter 10 was chosen for both similarity and area, whereas for the OLI/Landsat 8 sensor the values of 100 and 10 were those that presented the best fit.

The supervised classification was developed from the Bhattacharyya algorithm with $99 \%$ acceptance threshold (MATHER, 1999). The algorithm training process involved the acquisition of samples of the existing 
classes in the study area, which were: Native forest, which corresponds to fragments of the Mixed Ombrophilous Forest; Forest plantations, represented by homogeneous plots of Araucaria, pine, and eucalyptus; Native field, which corresponds to the native vegetation of this environment; and Water, represented by artificial reservoirs. After the classification of the images, thematic maps of the land use and cover were elaborated for the years of 1987 and 2017, is considered one date of each year, in the summer period. To verify if the changes between land use and land cover had a significant relationship with time (in years), the chi-square test validation statistic was applied at a significance level of $5 \%$.

To correlate the albedo information with the land use and land cover classes, each thematic class was individually transformed to vector and later extracted the albedo information from these classes. To avoid the inclusion of the edge pixels of the polygons in the descriptive statistics, which present a mixture of targets in the spectral response, a buffer was elaborated, subtracting 30 meters of the polygons from the edge. Finally, the descriptive analysis was performed using boxplot graphs containing the albedo values for each type of land use and coverage. This analysis, along with the other image processing, was performed using R-language functions.

\section{RESULTS}

Monitoring of the surface albedo for the São Francisco de Paula FLONA (Figure 2) showed that in 1987 (Figure 2a) the study area encompassed albedo values higher than the year 2017 (Figure 2b). It should be noted that in 2017, albedo values occupied lower classes, demonstrating a reduction of this climatic variable in the period evaluated.
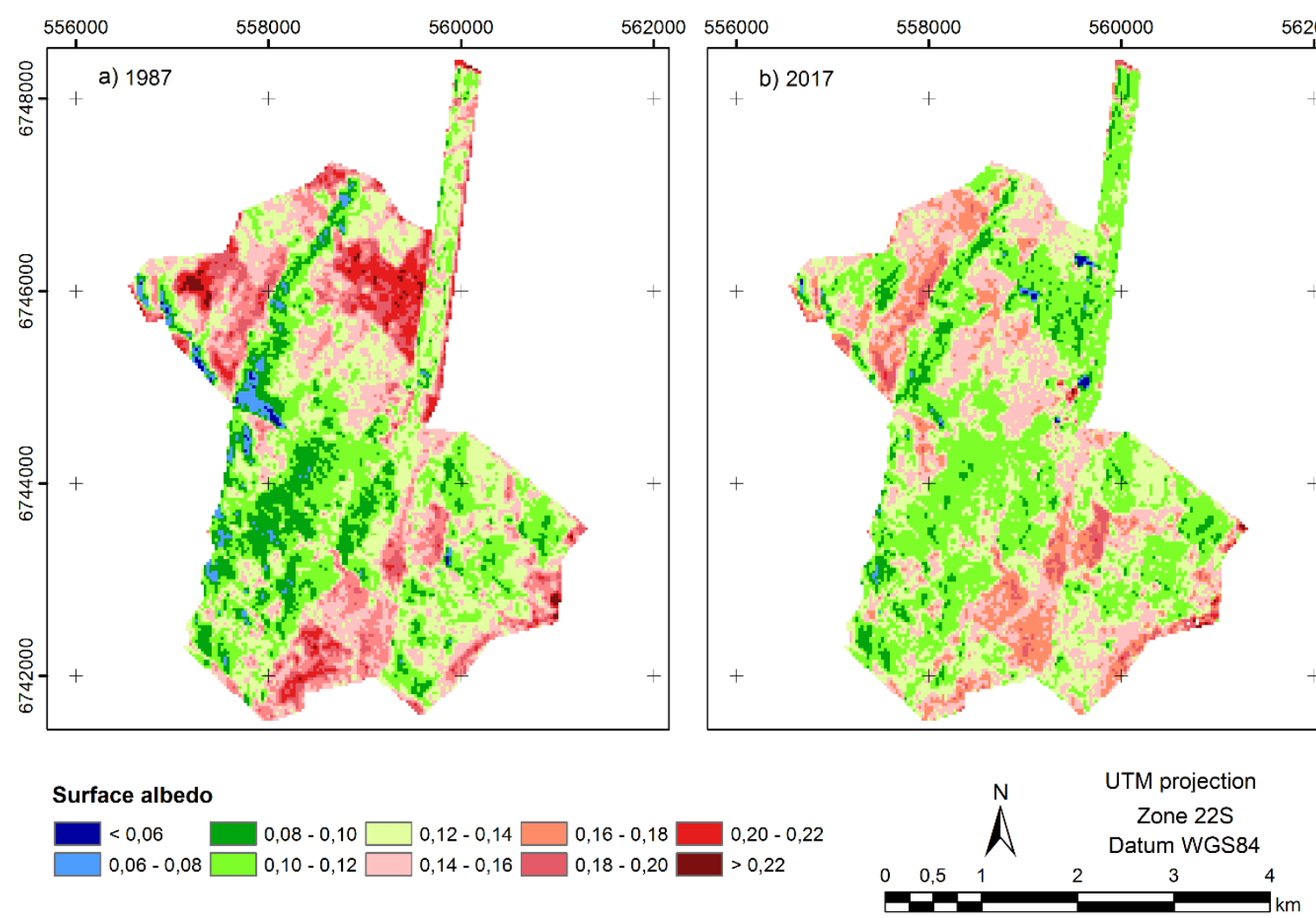

Figure 2. Surface Albedo in the FLONA of São Francisco de Paula in the years 1987 (a) and 2017 (b). Figura 2. Albedo de superfície na FLONA de São Francisco de Paula nos anos de 1987 (a) e 2017 (b).

For the FLONA of São Francisco de Paula, the surface albedo varied mainly from 6 to 22\%. The mapping of albedo showed that, in the mapping of 1987 , the predominant class was class 5 (0.12 to 0.14$)$, representing $26.50 \%$ of the total area, as shown in Table 1. In the same way, it should be noted that the beginning of monitoring concentrated a higher percentage of areas in the higher albedo classes when compared to the year 2017.

Table 1. Quantification of albedo for 1987 and 2017 in the FLONA of São Francisco de Paula.

Tabela 1. Quantificação do albedo para 1987 e 2017 na FLONA de São Francisco de Paula.

FLORESTA, Curitiba, PR, v. 50, n. 1, p. 1011 - 1020, jan/mar 2020.

Alba, E. et.al.

ISSN eletrônico 1982-4688

DOI: $10.5380 /$ rf.v50 i1.60595 


\begin{tabular}{|c|c|c|c|c|c|}
\hline \multirow{2}{*}{ Classes } & \multirow{2}{*}{$\begin{array}{l}\text { Surface } \\
\text { Albedo }\end{array}$} & \multicolumn{2}{|c|}{ Year of 1987} & \multicolumn{2}{|c|}{ Year of 2017} \\
\hline & & ha & $\%$ & ha & $\%$ \\
\hline 1 & $<0.06$ & 3.60 & 0.22 & 3.06 & 0.19 \\
\hline 2 & ד--- 0.080 .06 & 27.99 & 1.73 & 4.59 & 0.28 \\
\hline 3 & ד--- 0.100 .08 & 172.08 & 10.66 & 85.86 & 5.32 \\
\hline 4 & ז--- 0.120 .10 & 359.64 & 22.27 & 550.80 & 34.11 \\
\hline 5 & ד--- 0.140 .12 & 427.86 & 26.50 & 431.28 & 26.71 \\
\hline 6 & ן--- 0.160 .14 & 285.75 & 17.70 & 340.74 & 21.10 \\
\hline 7 & ו--- 0.180 .16 & 163.89 & 10.15 & 156.78 & 9.71 \\
\hline 8 & ד--- 0.200 .18 & 98.91 & 6.13 & 37.53 & 2.32 \\
\hline 9 & ק--- 0,20 0,18 & 66.92 & 4.14 & 2.97 & 0.18 \\
\hline 10 & $>0.22$ & 8.10 & 0.50 & 1.24 & 0.08 \\
\hline
\end{tabular}

As albedo values are related to the type of land surface cover, Figure 3 shows the mapping of land use and land cover for the years 1987 (Figure 3a) and 2017 (Figure 3b). In the final year of the monitoring, it observed the significant reduction of the native field class in the study area.

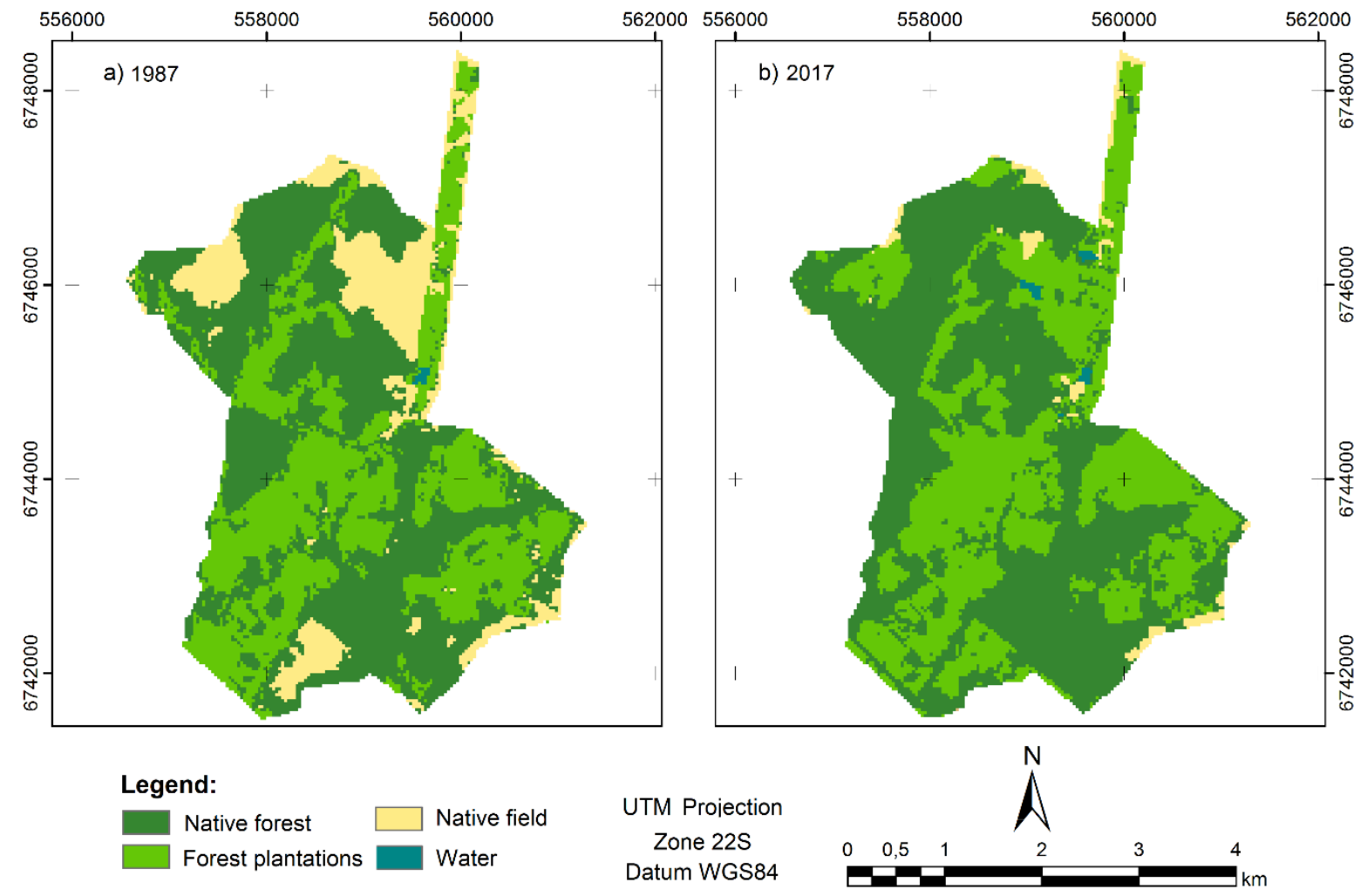

Figure 3. Use and land cover for FLONA of São Francisco de Paula in 1987 (a) and 2017 (b).

Figura 3. Uso e cobertura da terra para a FLONA de São Francisco de Paula nos anos de 1987 (a) e 2017 (b)

The native forest corresponded to the main cover, encompassing approximately $50 \%$ of the FLONA of São Francisco de Paula (Table 2). Following, forest plantations stand out representing 36\% and $42 \%$ of the total area in 1987 and 2017, respectively. Corroborating with the visual analysis, there was a reduction of the native field class after 30 years, from $14.28 \%$ in 1987 to $2.32 \%$ in 2017 , showing a reduction of $11.96 \%$ of the total area of FLONA occupied by the class. 
Table 2. Quantification of land use and land cover for 1987 and 2017 for FLONA of São Francisco de Paula. Tabela 2. Quantificação do uso e cobertura da terra para 1987 e 2017 para a FLONA de São Francisco de Paula.

\begin{tabular}{crrrrr}
\hline \multirow{2}{*}{ Thematic classes } & \multicolumn{2}{c}{ Year of 1987} & \multicolumn{2}{c}{ Year of 2017 } & \multicolumn{1}{c}{ Difference } \\
\cline { 2 - 6 } & \multicolumn{1}{c}{ ha } & \multicolumn{1}{c}{$\%$} & \multicolumn{1}{c}{ ha } & \multicolumn{1}{c}{$\%$} \\
\hline Native forest & 806.49 & 49.99 & 897.30 & 55.60 & +5.61 \\
Forest plantations & 574.29 & 35,60 & 673.20 & 41.71 & +6.11 \\
Native field & 230.31 & 14.28 & 37.44 & 2.32 & -11.96 \\
Water & 2.07 & 0.13 & 5.94 & 0.37 & +0.24 \\
\hline Total & 1613.16 & 100.00 & 1613.88 & 100.00 & 0.00 \\
\hline
\end{tabular}

The analysis of the crossing between the surface albedo and the different types of land use and the cover showed that the lowest values of albedo were identified on water surfaces, represented in the study area through artificial reservoirs (Figure 4). The water showed an average value of albedo lower to the other physiognomies.

a) 1987

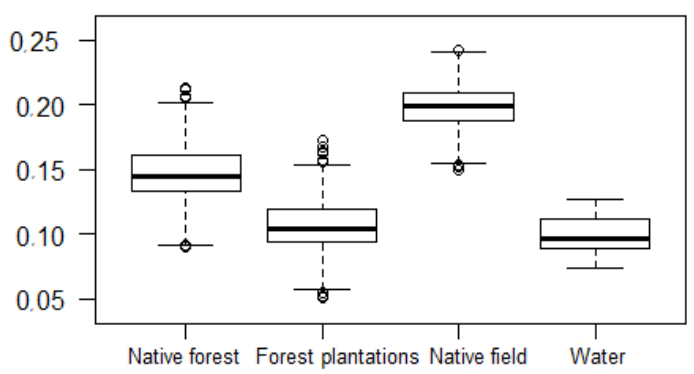

b) 2017

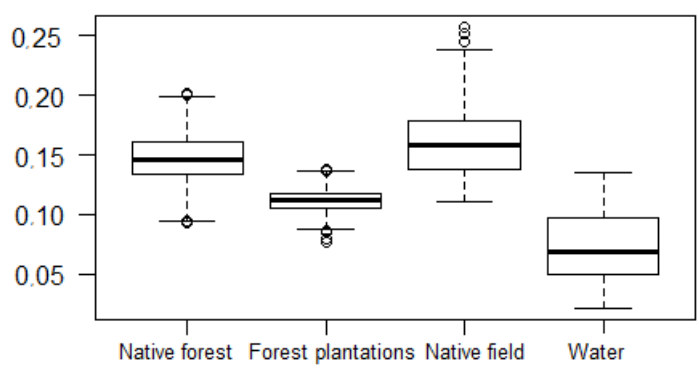

Figure 4. Boxplot graph for the thematic classes and their respective values of albedo in 1987 (a) and 2017 (b) for FLONA São Francisco de Paula.

Figura 4. Gráfico boxplot para as classes temáticas e seus respectivos valores de albedo nos anos 1987(a) e 2017 (b) para a FLONA São Francisco de Paula.

The highest values of surface albedo were identified in areas with little or no arboreal vegetation, corresponding to the field areas. This class showed the greatest deviations between the physiognomies in the mapping of 2017, showing a greater dispersion of the data around the mean. This variation can be attributed to the lower number of samples of this use at that date, associated with the formation of small clusters of pixels, many of them being uneven. In this process, the response stored in the uneven pixels is the result of a mixture of the components, such as forest, field, soil, among others, this interference being called spectral mixing, which implies a greater variation in albedo values.

\section{DISCUSSION}

According to the spatial analysis of the surface albedo presented by the FLONA of São Francisco de Paula, it was verified that in 1987 the values expressed for this variable were higher when compared to the values identified in 2017, since the presence of higher albedo classes at the beginning of the monitoring. The Southwest part of the study area presented lower values of albedo on both dates. However, the northern part of FLONA, after 30 years, the reduction of albedo values in the regions that previously comprised the largest classes, corresponding to values higher than 0.20, was identified. It should be noted that albedo classes 9 and 10 (albedo > 0.20) in 1987 represented $4.65 \%$ of the total area, while in 2017 these classes included only $0.25 \%$ of the area, confirming the behavior observed in the qualitative analysis of FLONA, to reduce the extreme values of albedo in 2017.

Corroborating this approach, it was identified that in 1987 the predominant class was 5, with albedo values between 0.12 and 0.14 , representing $26.50 \%$ of the total area, while in 2017 , the mapping indicated that class 4 , with albedo varying from 0.10 to 0.12 , encompassed the largest percentage of area, corresponding to $34.11 \%$ of FLONA.

Giongo and Vettorazzi (2014) obtained albedo values between $7 \%$ and $31 \%$ with the use of TM/Landsat 5 images in the state of São Paulo, while Dantas et al. (2010), using AVHRR/NOOAA images and TM/Landsat 5 in the monitoring of Caatinga, obtained albedo values ranging from $4 \%$ to $34 \%$. The albedo values of the present study encompassed a lower amplitude than that described in the literature, since the study area is predominantly

FLORESTA, Curitiba, PR, v. 50, n. 1, p. 1011 - 1020, jan/mar 2020.

Alba, E. et.al.

ISSN eletrônico 1982-4688

DOI: $10.5380 /$ rf.v50 i1.60595 
occupied with tree cover, and it does not present rock outcrop and/or exposed soil, which tend to present a greater loss of energy into the atmosphere, increasing the albedo values recorded by the sensor.

The variations presented by the albedo may be due to the predominance of certain types of surface cover (GIONGO; VETTORAZZI, 2014). Thus, the mapping of land use and land cover can be used to obtain answers regarding the variation of the climatic variable under study. The mapping was consistent with the data available in ICMBio (2017), where FLONA is composed predominantly of native forest and forest plantations. The field class is less expressive in the study area, which has been reduced in recent years.

The Southwest region of the study area, which showed the lowest albedo classes, showed the predominance of forest plantations of homogeneous crops. In contrast, the presence of the native field class was observed in 1987 (Figure 3a) in regions where the surface albedo encompassed the largest thematic classes (greater than 0.20 )

Changes in the native field over the 30 years of observation are noteworthy, demonstrating large area losses (Figure 3b). It is possible to identify that other uses in 2017 replaced most of the area covered by this class at the beginning of monitoring. The statistic validation of these results by the chi-square test resulted in a calculated value of 151.59 , while the table value was 3.84 , rejecting the null hypothesis. Thus, the native field presented significant differences in the percentage of area occupied in the study dates, validating the tendency to reduce the areas of this class. This same pattern was observed in other uses and land cover, except for Water, which according to the validation statistic, the area values presented in the two observation dates do not differ significantly.

At the end of the monitoring, the field gave space mainly to the Forest plantations, which expanded $6.11 \%$, followed by the native Forest with an increase of $5.61 \%$ in the period. Less expressive, water presented a $0.24 \%$ increase in the total area accounting. Field areas that were replaced by forest plantations were mainly occupied by Pinus spp.

Through the cross-reference of the thematic maps, the contribution of each class of use with its respective albedo values was observed. The results obtained in this study corroborate with Giongo and Vettorazzi (2014), who obtained a percentage of albedo between 6 and $11 \%$ for the dams. For Kuusinen et al. (2013), the water blades presented an average albedo value of $5.6 \%$ associated with one of the smallest deviations when compared to other types of land use and land cover.

The forest cover of the study area, represented by the native forest and forest plantations, presented intermediate values of albedo, with a median of less than 0.14 . Similar behavior was reported by Lukes et al. (2014), who observed albedo values below $15 \%$ in the summer when studying the boreal forest with MODIS data. However, the forest stands showed lower albedo values when compared to the native forest. Thus, forest plantations presented median values of 0.11 in both dates, while the native forest was approximately 0.14 .

The structural characteristics of the leaves, as well as the organization of the canopy and understorey, influence the reflected and emitted forest response. According to Lukes et al. (2014), the architecture of the canopies, comprising several hierarchical levels, corresponds to one of the main factors that differ forest albedo. Besides, forest plantations have one of the smallest deviations, while native forests have shown a greater dispersion of the data around the average value of the albedo when comparing these two classes, and this behavior was best observed in 2017.

The forest stands present in the study area are composed of coniferous and hardwood species. In this perspective, Kuusinen et al. (2013) identified an average albedo during the summer of 0.105 for coniferous forests, while deciduous species showed an albedo of 0.143 in a boreal forest.

Knowing the albedo of the forests under different management practices and composition of species allows to better evaluate the contributions to the climate that the forestry has at the local scale, advancing in the issues of carbon sequestration. In this context, studies related to forest cover albedo may contribute to the development of management proposals contemplating both perspectives.

\section{CONCLUSION}

- Changes in plant cover cause changes in the albedo, interfering with radiation and atmospheric fluxes. Thus, this methodology can be applied in climate change assessment studies, as well as to identify the contribution of forests to climate processes

- The monitoring of the albedo exposed the reduction of the values of this variable after 30 years, with the highest albedo values being associated with the native field.

- Forest cover presented lower albedo values than other land uses and cover. The changes of albedo in this physiognomy are represented, to a large extent, by the influence of the canopy structure on the spectral response 


\section{REFERENCES}

ALLEN, R. G.; TASUMI, M.; TREZZA, R. Satellite-based energy balance for mapping evapotranspiration with internalized calibration (METRIC) - Model. Journal of Irrigation and Drainage Engineering, Reston, v. 133, p. 380 - 394, 2007.

BASTIAANSSEN, W. G. M. Regionalization of surface flux densities and moisture indicators in composite terrain: A remote sensing approach under clear skies in Mediterranean climate. Tesis. Netherlands: CIP Data Koninklijke Biblioteheek, Den Haag, 1995. 272 p.

DANTAS, F. R. C.; BRAGA, C. C.; SOUZA, E. P.; SILVA, S. T. A. Determinação do albedo da superfície a partir de dados AVHRR/NOAA e TM/Landsat-5. Revista Brasileira de Meteorologia, São José dos Campos, v. 25 , n. 1 , p. $24-31,2010$.

DAVIN, E. L.; NOBLET-DUCOUDRÉ, N. Climatic impact of global-scale deforestation: Radiative versus Nonradiative processes. Journal of Climate, Washington, v. 23, p. 97 - 112, 2010.

GIONGO, P. R.; VETTORAZZI, C. A. Albedo da superfície por meio de imagens TM-Landsat 5 e modelo numérico do terreno. Revista Brasileira de Engenharia Agrícola e Ambiental, Campina Grande, v. 18, n. 8, p. $833-838,2014$.

HAHMANN, A. N. e DICKINSON, R. E. Modelo RCCM2-BATS sobre a América do Sul tropical: aplicações ao desmatamento tropical. Journal of Climate, Washington, v. 10, p. 1944 - 1964, 1997.

HE, T.; LIAN, S.; WANG, D.; CAO, Y.; GAO, F.; YU, Y.; FEND, M. Evaluating land surface albedo estimation from Landsat MSS, TM, ETM +, and OLI data based on the unified direct estimation approach. Remote Sensing of Environment, v. 204, p. 181 - 196, jan. 2018.

INSTITUTO CHICO MENDES DE CONSERVAÇÃO DA BIODIVERSIDADE - ICMBIO. Floresta Nacional de São Francisco de Paula/RS. 2017.

JENSEN, J. R. Sensoriamento remoto do ambiente: uma perspectiva em recursos terrestres. Tradução de José Carlos Neves Epiphanio (coordenador)...[et al.]. São José dos Campos, SP: Parêntese, 2009. 598 p.

LI, Z.; BHATT, U.S.; MÖLDERS, N. Impact of doubled CO2 on the interaction between the global and regional water cycles in four study regions. Climate Dynamics, Switzerland, v. 30, p. 255 - 275, 2008.

LIBERATO, A. M. Albedo à superfície a partir de imagens Landsat 5 -TM em áreas de floresta e pastagem na Amazônia. Revista de Geografia, Recife, v. 28, p. 110 - 119, n. 1, 2011.

LUKES, P.; STENBERG, P.; MÕTTUS, M.; MANNINEN T.; RAUTIAINEN, M. Multidecadal analysis of forest growth and albedo in boreal Finland. International Journal of Applied Earth Observation and Geoinformation, v. 52, p. 296 - 305, 2016.

LUKES, P.; RAUTIAINEN, M.; MANNINEN, T.; STENBERG, P.; MÕTTUS, M. Geographical gradients in boreal forest albedo and structure in Finland. Remote Sensing of Environment, v. 152, p. 526 - 535, 2014.

LUKES, P.; STENBERG, P.; RAUTIAINEN M. Relationship between forest density and albedo in the boreal zone. Ecological Modelling, v. 261 - 262, p. 74 - 79, 2013.

KANIESKI, M. R.; SOLON, S. J. L.; MILANI, J. E. F.; SANTOS, T. L.; SOARES, P. R. C. Caracterização florística e diversidade na floresta nacional de São Francisco de Paula, RS, Brasil. Revista Floresta, Curitiba, v. 47, n. 2, p. 177 - 185, 2017.

KUUSINEN, N.; STENBERG, P.; KORHONEN, L.; RAUTIAINEN, M.; TOMPPO, E. Structural factors driving boreal forest albedo in Finland. Remote sensing of environment, v. 175, n. 9, p. 43 - 51, 2016.

KUUSINEN, N; TOMPPO, E.; BERNINGER, F. Linear unmixing of MODIS albedo composites to infer subpixel land cover type albedos. International Journal of Applied Earth Observation and Geoinformation, v. 23, p. $324-333,2013$.

MATHER, P. M. Computer processing of remotely sensed images: an introduction. 2.ed. Chinchester: John Wiley, 1999, $292 \mathrm{p}$.

PLANQUE, C.; CARRER, D.; ROUJEAN, J. L. Analysis of MODIS albedo changes over steady woody covers in France during the period of 2001-2013. Remote Sensing of Environment, v. 191, n. 2017, p. 13 - 29 , 2017.

FLORESTA, Curitiba, PR, v. 50, n. 1, p. 1011 - 1020, jan/mar 2020.

Alba, E. et.al.

ISSN eletrônico 1982-4688

1019

DOI: 10.5380/rf.v50 i1.60595 
R DEVELOPMENT CORE TEAM. R: The language and environment for statistical computing. Vienna: $\mathrm{R}$ Foundation for Statistical Computing, 2017. Recuperado de http://www.R-project.org.

SILVA, B. B.; BRAGA, A.; BRAGA, C.; OLIVEIRA, L. M. M.; MONTENEGRO, S. M. G. L.; BARBOSA JUNIOR, B. Procedures for calculation of the albedo with OLI-Landsat 8 images: Application to the Brazilian semi-arid. Revista Brasileira de Engenharia Agrícola e Ambiental, Campina Grande, v. 20, n. 1, p. 3 - 8, 2016.

SONEGO, R. C.; BACKES, A.; SOUZA, A. F. Descrição da estrutura de uma Floresta Ombrófila Mista, RS, Brasil, utilizando estimadores não-paramétricos de riqueza e rarefação de amostras. Acta Botânica Brasílica, Belo Horizonte, v. 24, n. 4, p. 943 - 955, 2007.

UNITED STATES GEOLOGICAL SURVEY - USGS. Landsat missions. 2017. Disponível em: < https://www.usgs.gov/land-resources/nli/landsat>. Acesso em: 10 jan. 2017. 